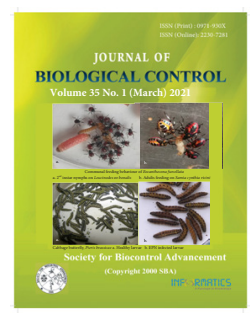

Research Note

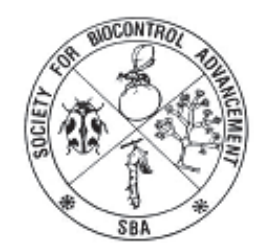

\title{
Ovicidal action of different fungal pathogens against two spotted spider mite, Tetranychus urticae (Koch) under laboratory conditions
}

\author{
S. SARANYA*, K. RAMARAJU and S. JEYARANI \\ Department of Agricultural Entomology, Tamil Nadu Agricultural University, Coimbatore, Tamil Nadu, India \\ *Corresponding authorE-mail: saransellamuthu@gmail.com
}

\begin{abstract}
Bioassay studies were performed with ten different fungal isolates of six species against two spotted spider mite, Tetranychus urticae. Among different formulations, Hirsutella thompsonii caused significantly higher mortalities of $61.1,35.8$ and 22.1 per cent at conidial concentrations of 971, 196 and 36 conidia $\mathrm{mm}^{-2}$, respectively. At a conidial concentration of 1457 conidia mm $^{-2}$, Beauveria bassiana isolate Bb101 caused significantly higher mortality rate of 46.9 per cent followed by B. bassiana isolate B2 (36.1\%) and Cladosporium cladosporioides isolate $\mathrm{Cc} 101$ (32.1\%). Based on the probit estimates, H. thompsonii was found to exert high ovicidal activity with the lowest $\mathrm{LC}_{50}$ of 674 conidia $\mathrm{mm}^{2}$ against $T$. urticae eggs.
\end{abstract}

KEY WORDS: Entomopathogenic fungi, ovicidal effect, Tetranychus urticae

(Article chronicle: Received: 24-02-2021; Revised: 29-03-2021; Accepted: 30-03-2021)

The Two Spotted Spider Mite (TSSM), Tetranychus urticae Koch, is a ubiquitous agricultural pest with a global distribution. It is a major concern in vegetables causing heavy damage leading to 7 to 48 per cent yield loss (Srinivasa and Sugeetha, 1999). Its phytophagous nature, high reproductive potential, extremely short life cycle and arrhenotokous mating system facilitate rapid resistance development to many acaricides often after a few applications. Therefore, screening of suitable biocontrol agents is a step in developing new or improving existing environment friendly strategies offering an alternative to conventional pest control. Entomopathogenic fungi may play a major role in the natural regulation of spider mite populations and could be used in biological control programme, either as a replacement for synthetic acaricides or as a component of integrated mite management.

Several studies have been conducted for identifying the ovicidal action of entomopathogenic fungi against mites. Hanchinal and Manjunatha (2000) reported the pathogenicity of Metarhizium anisopliae on eggs of T. neocaledonicus. The per cent mortalities of eggs were 21.37, 38.50 and 87.82, at one, two and three days, respectively. Irigaray et al. (2003) reported that a commercial Beauveria bassiana formulation, Naturalis, had high ovicidal action against eggs of T. urticae within 1-3 days of its application containing 1,400-22,800 viable conidia $\mathrm{ml}^{-1}$.

Acevedo et al. (2003) reported that the exudates produced by the Hirsutella thompsonii inhibited egg production by female spider mites. Topical application of the metabolite resulted in 100 per cent reduction in fecundity in T. urticae over a 6 day post treatment period. Kumar and Singh (2007) found that $T$. urticae eggs treated with the exudate from sporulating culture of $H$. thompsonii showed very significant $(64.6 \%)$ reduction in hatching. In the fecundity test, an adult female feeding on leaves treated with exudates laid only 30.7 eggs compared to untreated leaf (51eggs/female) laid over a period of 7 days.

In the present study, ten different fungal isolates were evaluated for their ovicidal action against TSSM, Tetranychus urticae.

\section{Preparation of mite eggs}

Around 20 adult females of $T$. urticae were arbitrarily taken from the plants and transferred onto a detached okra leaf disc $(50 \mathrm{~mm})$ placed on 1.5 per cent agar in a Petri dish and allowed to lay eggs for $24 \mathrm{~h}$. Subsequently, the females were removed, leaving 30 eggs per leaf disc, for bioassays. 
Ovicidal action of different fungal pathogens against two spotted spider mite The detached leaf disc on agar remained turgid for over seven days so as to allow normal hatching of the mite eggs.

\section{Source of the fungal isolates}

Pure cultures of the entomopathogenic fungi viz. Paecilomyces fumosoroseus (Thom.) and Hirsutella thompsonii (Fisher) were obtained from the National Bureau of Agricultural Insect Resources (NBAIR), Bangalore and Beauveria bassiana (Balsamo) Vuillemin (B2 strain) from Department of Plant Pathology, Tamil Nadu Agricultural University (TNAU), Coimbatore. Local isolates viz., Cladosporium cladosporioides (Fresenius) de Vries, Fusarium pallidoroseum Cooke (Sacc), B. bassiana and Metarhizium anisopliae (Metchinkoff) Sorokin were obtained during surveys.

\section{Bioassays on eggs of Tetranychus urticae}

Spore suspensions of six different fungal pathogens and ten isolate (Beauveria bassiana - Bb101, Bb102, Bb103, B2, Metarhizium anisopliae - Ma101, Fusarium pallidoroseum - Fp101, Cladosporium cladosporioides - Cc101, Cc102, Paecilomyces fumosoroseus- Pfr and Hirsutella thomsoni $\mathrm{Ht}$ ) were prepared separately and standardized at the concentration of $1 \times 10^{8}, 10^{7}$ and $10^{6}$ spores $\mathrm{ml}^{-1}$. Bioassay was done with the slight modifications as per the procedure of Shi and Feng (2004a). For each fungal isolate, three detached leaves with eggs in uncovered Petri dishes were placed onto the bottom of a large bucket ( $48 \mathrm{~cm}$ diameter and $60 \mathrm{~cm}$ height). Three glass cover slips $(20 \times 20 \mathrm{~mm})$ were triangularly placed on the bucket bottom (besides each of the Petri dishes) to collect the sprayed conidia while the eggs were exposed. Then, counts of conidia on each cover slip were made from five randomly sampled view fields under a compound microscope at 400 $\mathrm{x}$ magnification and averaged as the number of conidia per $\mathrm{mm}^{2}$. Thus, the three different concentrations of each fungal isolate resulted in low, intermediate and high concentrations of conidia attached to the eggs and leaves. A spray of 0.05 per cent Tween $80^{\circledR}$ served as blank control. All the treatments were replicated three times.

After spray, all the treated Petri dishes were maintained in an incubator at $25^{\circ} \mathrm{C}$ and examined daily for three days. Later, the eggs were individually examined under a stereo zoom binocular microscope (Carl zeiss Stemi 2000) at 40x magnification for verification of fungal infection. Finally, all unhatched eggs were transferred to moist chambers for two or three days to observe fungal outgrowth if any, as an evidence of egg mortality due to fungal infection.

Ovicidal activity of ten fungal isolates studied against T. urticae under laboratory conditions revealed that $H$. thompsonii was more effective against $T$. urticae eggs with pronounced ovicidal activity. A significant reduction $(61.1 \%)$ in hatchability was observed at the higher conidial concentration of 971 conidia $\mathrm{mm}^{-2}$. It was concurrent with the results of Kumar and Singh (2007), which treated the $T$. urticae eggs with the $H$. thompsonii exudates and noticed a significant reduction (64.6\%) in hatching.

The isolate $\mathrm{Bb} 101$ caused significantly higher egg mortality rate of 46.9 per cent followed by B2 (36.1\%) and Cc101 (32.1\%) at higher conidial concentration of 1457 , 1231 and 856 conidia $\mathrm{mm}^{-2}$, respectively. In other isolates, mortality per cent ranged from 29.3 to 14.7 and was found to be low, which may be due to less sporulation of the isolates. Perhaps the duration of the egg stage (1-2 days) was too short for the fungal mycelium to cause infection of less sporulated cultures (Mazet and Vey, 1995). Based on the $\mathrm{LC}_{50}$ estimates determined by the concentration mortality relationships for all fungal pathogens, $H$. thompsonii was more lethal to the eggs of T. urticae with lower $\mathrm{LC}_{50}$ $\left(674\right.$ conidia $\mathrm{mm}^{-2}$ ). The two isolates $\mathrm{Ht}$ and $\mathrm{Bb} 101$ were highly infective to spider mite eggs. The $\mathrm{Ht}$ isolate had a $\mathrm{LC}_{50}$ apparently lesser than 1718 conidia $\mathrm{mm}^{-2}$ of the $\mathrm{Bb} 101$ isolate, indicating its stronger ovicidal action and $\mathrm{Bb} 101$ was moderately infective to eggs. The high ovicidal activity of $H$. thompsonii isolate may be due to its insecticidal and acaricidal metabolite Hirsutellin A, a toxic compound secreted in the broth culture (Liu et al., 1995).

The results obtained in the present study also corroborates with the findings of Shi and Feng (2004 a) who reported that application of $B$. bassiana conidia to $T$. cinnabarinus eggs at the concentrations of 58,298 and 1306 conidia $\mathrm{mm}^{-2}$ resulted in corrected egg mortalities of $20.4 \pm 4.2$ per cent, $36.0 \pm 7.6$ per cent and $64.6 \pm 12.5$ per cent, respectively. Shi and Feng (2004 b) found that B. bassiana $\mathrm{Bb} 2860$ was highly infectious to T. cinnabarinus eggs with the lowest $\mathrm{LC}_{50}$ of 548 conidia $\mathrm{mm}^{-2}$, followed by $P$. fumosoroseus Pfr116 (848 conidia $\mathrm{mm}^{-2}$ ) and Pfr153 (913 conidia $\mathrm{mm}^{-2}$ ).

Unlike active immature and adult stages, the eggs are immobile, making it difficult to determine their mortality status. Slight changes in egg morphology such as shape and colour were not sufficient to judge the mortality. Thus, the unhatched eggs observed on a given day after spray could not be classified as dead or alive until fungal outgrowths were visible. Fortunately, counts of the hatched eggs could be easily attained, generating an overview to the effect of different fungal sprays on their hatch rates over time which can be used to assess the egg mortalities at different conidial concentrations.

Entomopathogenic fungi have evolved with the insects, 
a hundred million years ago and are still evolving. They are part of our natural environment and have interacted with pest management as long as their existence. In the present study, utilization of native strains with the increased virulence and pathogenicity provides specific action on host and adaptation to the environment. Successful use of entomopathogenic fungi as microbial control agents of mites depends on the virulent strains, formulation, and compatibility with other control agents, better delivery system and timing of applications. Hence, the use of fungal entomopathogens serves as an alternative to acaricides and offers a great scope in bio intensive pest management with safety to environment as an added advantage over chemicals.

Table 1. Ovicidal action of different fungal isolates against Tetranychus urticae

\begin{tabular}{|c|c|c|c|c|c|}
\hline Fungal isolate ${ }^{\#}$ & No. of Conidia $\mathrm{mm}^{-2}$ & $\begin{array}{c}\text { Egg } \\
\text { Mortality (\%) }\end{array}$ & Fungal isolate & No. of Conidia $\mathrm{mm}^{-2}$ & $\begin{array}{c}\text { Egg } \\
\text { Mortality (\%) }\end{array}$ \\
\hline \multirow{4}{*}{$\begin{array}{l}\text { B. bassiana } \\
\text { Bb101 }\end{array}$} & 1457 & $46.9^{\mathrm{a}}$ & \multirow{4}{*}{$\begin{array}{l}\text { F. pallidoroseum } \\
\text { Fp } 101\end{array}$} & 984 & $29.3^{\mathrm{a}}$ \\
\hline & 539 & $30.2^{\mathrm{b}}$ & & 239 & $17.4^{\mathrm{b}}$ \\
\hline & 87 & $8.8^{c}$ & & 65 & $6.05^{\mathrm{c}}$ \\
\hline & Control & $3.0^{\mathrm{d}}$ & & Control & $3.5^{\mathrm{c}}$ \\
\hline \multirow{4}{*}{$\mathrm{Bb} 102$} & 1384 & $14.7^{\mathrm{a}}$ & \multirow{4}{*}{$\begin{array}{c}\text { C.cladosporioides } \\
\text { Cc101 }\end{array}$} & 791 & $16.9^{\mathrm{a}}$ \\
\hline & 593 & $7.9^{\mathrm{b}}$ & & 282 & $6.4^{\mathrm{b}}$ \\
\hline & 75 & $2.9^{\mathrm{c}}$ & & 84 & $6.2^{\mathrm{b}}$ \\
\hline & Control & $3.0^{\mathrm{c}}$ & & Control & $3.6^{\mathrm{b}}$ \\
\hline \multirow{4}{*}{$\mathrm{Bb} 103$} & 1144 & $19.4^{\mathrm{a}}$ & \multirow{4}{*}{ Cc102 } & 856 & $32.1^{\mathrm{a}}$ \\
\hline & 509 & $12.0^{\mathrm{b}}$ & & 248 & $24.3^{\mathrm{b}}$ \\
\hline & 68 & $3.4^{\mathrm{c}}$ & & 79 & $19.9^{\mathrm{b}}$ \\
\hline & Control & $3.1^{\mathrm{c}}$ & & Control & $3.6^{\mathrm{c}}$ \\
\hline \multirow{4}{*}{ B2 } & 1231 & 36.1 & \multirow{4}{*}{$\begin{array}{c}\text { P. fumosoroseus } \\
\text { Pfr }\end{array}$} & 1168 & $15.0^{\mathrm{a}}$ \\
\hline & 474 & 26.5 & & 476 & $12.3^{\mathrm{a}}$ \\
\hline & 64 & 13.6 & & 64 & $6.8^{b}$ \\
\hline & Control & 6.6 & & Control & $4.3^{\mathrm{b}}$ \\
\hline \multirow{4}{*}{$\begin{array}{l}\text { M. anisopliae } \\
\text { Ma } 101\end{array}$} & 1147 & $25.8^{\mathrm{a}}$ & \multirow{4}{*}{$\begin{array}{c}\text { H. thompsonii } \\
\mathrm{Ht}\end{array}$} & 971 & $61.1^{\mathrm{a}}$ \\
\hline & 294 & $17.6^{\mathrm{b}}$ & & 196 & $35.8^{\mathrm{b}}$ \\
\hline & 57 & $10.6^{\mathrm{c}}$ & & 36 & $22.1^{\mathrm{c}}$ \\
\hline & Control & $2.9^{\mathrm{d}}$ & & Control & $4.9^{\mathrm{d}}$ \\
\hline
\end{tabular}

\# Number of eggs used per treatment - 30

Means followed by a common letter ( $\mathrm{s}$ ) are not significantly different at $\mathrm{P}=0.05$ by LSD

Table 2. Concentration mortality response of Tetranychus urticae eggs to different fungal isolates

\begin{tabular}{|l|c|c|c|c|c|}
\hline Fungal Isolates & No. of eggs used & $2 *$ & Regression equation & $\begin{array}{c}\text { Lc }_{50} \\
(\text { No. of conidia } \\
\left.\mathrm{mm}^{-2}\right)\end{array}$ & $\begin{array}{c}95 \% \text { Fiducial Limits } \\
\left(\mathrm{No} . \text { of conidia mm }^{-2}\right)\end{array}$ \\
\hline B. bassiana Bb101 & 30 & 0.034 & $\mathrm{Y}=1.042 \mathrm{X}-3.37$ & 1718 & $1126-3471$ \\
\hline Bb102 & 30 & 0.264 & $\mathrm{Y}=0.67 \mathrm{X}-3.20$ & 5755 & $8259-22589$ \\
\hline Bb103 & 30 & 1.303 & $\mathrm{Y}=0.001 \mathrm{X}-1.72$ & 2169 & $1617-4071$ \\
\hline B2 & 30 & 0.037 & $\mathrm{Y}=0.576 \mathrm{X}-2.147$ & 5380 & $1907-12167$ \\
\hline M. anisopliae Ma 101 & 30 & 0.608 & $\mathrm{Y}=0.001 \mathrm{X}-1.19$ & 2229 & $1488-66665$ \\
\hline F. pallidoroseum Fp 101 & 30 & 0.466 & $\mathrm{Y}=0.818 \mathrm{X}-2.69$ & 4196 & $1726-38952$ \\
\hline C. cladosporioides Cc101 & 30 & 1.518 & $\mathrm{Y}=0.024 \mathrm{X}-1.547$ & 1930 & $1317-5008$ \\
\hline Cc102 & 30 & 0.134 & $\mathrm{Y}=0.12 \mathrm{X}-0.849$ & 1851 & $1097-205020$ \\
\hline P. fumosoroseus & 30 & 0.601 & $\mathrm{Y}=0.11 \mathrm{X}-1.43$ & 3908 & $2345-6321$ \\
\hline H. thompsonii & 30 & 1.673 & $\mathrm{Y}=0.12 \mathrm{X}-0.688$ & 674 & $524.3-896.6$ \\
\hline
\end{tabular}

*All lines are significantly good fit at $\mathrm{P} \leq 0.05$ 
Ovicidal action of different fungal pathogens against two spotted spider mite

\section{REFERENCES}

Acevedo RJL, Boucia DG, Lezama R, Sims K, Pescador A. 2003. Exudate from sporulating cultures of Hirsutella thompsonii inhibit oviposition by the two spotted spider mite Tetranychus urticae. Exp Appl Acarol. 29: 213-225. https://doi.org/10.1023/A:1025801817004

Hanchinal SG, Manjunatha M. 2000. Metarhizium anisopliae (Metsch.) Sor. on Tetranychus neocaledonicus Andre and its predator Amblyseius ovalis Evans. Karnataka J Agric Sci. 13(2): 454-456.

Irigaray FJS, Marco-Mancebón V, Pérez-Moreno I. 2003. The entomopathogenic fungus Beauveria bassiana and its compatibility with triflumuron: effect on the two-spotted spider mite, Tetranychus urticae. Biol Control, 26(2): 168-173. https://doi.org/10.1016/S10499644(02)00123-8

Kumar PS, Singh L. 2007. Acarotoxicity of Hirsutella thompsonii Fisher exudate with reference to the twospotted spider mite, Tetranychus urticae Koch. J. Biol Control, 21: 197-202.
Mazet, I., Vey A. 1995. Hirsutellin A, toxic protein produced in vitro by Hirsutella thompsonii. Microbiology. 141: 1343-1348. https://doi.org/10.1099/13500872-141-61343

Shi, WB, Feng MG. 2004a. Ovicidal activity of two fungal pathogens (Hyphomycetes) against Tetranychus cinnabarinus (Acari: Tetranychidae). Chinese Sci Bull. 49(3): 263-267. https://doi.org/10.1007/BF03182810

Shi, WB, Feng MG. 2004b. Lethal effect of Beauveria bassiana, Metarhizium anisopliae, and Paecilomyces fumosoroseus on the eggs of Tetranychus cinnabarinus (Acari: Tetranychidae) with a description of a mite egg bioassay system. Biol Control, 30: 165-173. https://doi. org/10.1016/j.biocontrol.2004.01.017

Srinivasa, N, Sugeetha J. 1999. Bio effectiveness of certain botanicals and synthetic pesticides against okra spider mite Tetranychus macfarlanei. J Acarol. 15: 1-5. 